\title{
Diversification of tourism and economic development of Kazakhstan
}

\author{
Aksanat Zh. Panzabekova \\ Institute of Economics of the Committee of Science of the Ministry of Education and Science \\ of the Republic of Kazakhstan, Almaty, Kazakhstan; e-mail: aksanat@mail.ru
}

\begin{abstract}
The article aims to demonstrate how the economic conditions of Kazakhstan determine the need for horizontal diversification in the tourism industry by analyzing the correlations between the volume of tourism services and such indicators as the GDP, unemployment, tenge exchange rate, inflation and the number of small and medium-sized enterprises. The overview of the tourism industry in the republic and its development prospects shows that tourism has been playing an increasingly important role in the country's economy. The negative factors that hinder development of the tourism industry in Kazakhstan include the lack of transport and information infrastructure, the unstable banking sector and unaffordable business loans, the lack of qualified personnel in marketing, catering and hospitality spheres. A conclusion is made that the potential for the development of recreation, sport, cultural, ecological and religious tourism is not fully realized in the country and that a more diversified portfolio of tourism products is required. Moreover, it is necessary to enhance the country's economic growth, that is, to reduce its dependence on oil and gas, support the development of the banking sector and implement structural reforms. The results of this research can be used for designing state and regional tourism support programs in Kazakhstan.
\end{abstract}

\section{KEYWORDS}

Identification, diversification, tourism, economic development, Kazakhstan

\section{FOR CITATION}

Panzabekova, A. Zh. (2018)

Diversification of tourism and economic development of Kazakhstan. R-economy, 4(3), 82-87. doi:

10.15826/recon.2018.4.3.012

\section{Диверсификация туризма и экономического развития Казахстана}

\author{
А. Пазанбекова \\ Институт экономики Комитета науки Министерства образования и науки Республики Казахстан, \\ Алматы, Казахстан; e-mail: aksanat@mail.ru
}

\section{РЕЗЮМЕ}

Целью статьи является демонстрация того, как экономические условия Казахстана определяют необходимость горизонтальной диверсификации в индустрии туризма путем анализа корреляций между объемом туристических услуг и такими показателями, как ВВП, безработица, обменный курс тенге, инфляция и количество мелких и средних предприятий. Обзор индустрии туризма в республике и перспектив ее развития показывает, что туризм играет все более важную роль в экономике страны. Отрицательными факторами, препятствующими развитию индустрии туризма в Казахстане, являются отсутствие транспортной и информационной инфраструктуры, нестабильный банковский сектор и недоступные бизнес-кредиты, отсутствие квалифицированного персонала в сферах маркетинга, общественного питания и гостиничного бизнеса. В статье сделан вывод о том, что потенциал развития рекреационного, спортивного, культурного, экологического и религиозного туризма в стране не полностью реализован и что требуется более диверсифицированный портфель туристических продуктов. Более того, необходимо усилить экономический рост страны, то есть уменьшить зависимость от нефти и газа, поддержать развитие банковского сектора и провести структурные реформы. Результаты этого исследования могут быть использованы для разработки государственных и региональных программ поддержки туризма в Казахстане.

\section{КЛЮЧЕВЫЕ СЛОВА}

идентификация, диверсификации, туризм, экономическое развитие, Казахстан

\section{ДЛЯ ЦИТИРОВАНИЯ}

Panzabekova, A. Zh. (2018) Diversification of tourism and economic development of Kazakhstan. R-economy, 4(3), 82-87. doi:

10.15826/recon.2018.4.3.012 


\section{Introduction}

The travel and tourism industry is subject to a range of external pressures, such as political and economic instability in tourist destination regions as well as demographic processes in the countries where tourism companies are located [1]. Therefore, diversification of tourist packages, geographical markets, and tourism technologies is widely used in developed countries. In Kazakhstan, this can prove to be a viable solution for the problems the tourism industry is currently facing, making this sector more flexible and adaptable to change.

There is a vast body of research that deals with various aspects of diversification in tourism: for instance, the question of priorities in diversification on the level of individual enterprises [2-4], on the level of rural areas, regions and countries [5-8].

This paper aims to show how the current economic conditions in Kazakhstan determine the need to diversify the portfolio of tourism products in Kazakhstan to make the industry more efficient.

\section{Methodology}

Our methodology is based on dialectic, systemic, and descriptive approaches, which allow us to study the problem by adopting the method of scientific abstraction, logical analysis, comparison, cause and effect analysis. By applying these methods and approaches, we analyze the link between diversification in tourism industry and the country's economic development and identify the factors that influence the development of tourism in Kazakhstan. Therefore, we have chosen the following key economic indicators: GDP, unemployment, tenge exchange rate, inflation, and the number of small and medium-sized enterprises (SMEs). We also analyzed the data provided by international organizations' reports.

\section{General characteristics of the tourism industry in Kazakhstan}

Tourism is one of the main sectors of economy in Kazakhstan, crucial for the country's social, cultural and environmental development.

Although tourism is one of the world's largest industries, ranking third in terms of revenues after oil and gas industry and car manufacturing [9], in Kazakhstan, it accounts for only $0.9 \%$ of the GDP. According to The Travel \& Tourism Competitiveness Report of the 2017 World Economic Forum, Kazakhstan ranks $81^{\text {st }}$ among 136 countries $^{1}$.

Kazakhstan Ranks $81^{\text {st }}$ in the WEF Travel \& Tourism Competitiveness Index. Retrieved from https://informburo.kz/ novosti/kazahstan-zanyal-81-mesto-v-reytinge-konkurentosposobnosti-v-sfere-turizma.html
In 2017, the government of Kazakhstan adopted the Roadmap for Tourism Development in Kazakhstan, which set the target of increasing the share of tourism in the GDP to $8 \%$ by $2025^{2}$.

Current trends in the development of tourism in Kazakhstan can lead to the improvement of the situation in the future: for instance, while in 2000, 1.47 million of foreign tourists visited Kazakhstan, their number rose to 7.7 million in $2016^{3}$.

At the same time, according to international experts, tourism in Kazakhstan still has a long way to go, despite the abundance of sites of outstanding natural beauty. The negative factors that are off-putting to tourists are the poor quality of services and the lack of developed transport infrastructure ${ }^{4}$.

Research literature identifies three major types of tourism - inbound, outbound and domestic. As for the purpose of travel, we can distinguish cultural, ethnic, religious, sport, recreational, educational, exotic, ecological, transit, rural, adventure, medical, space, event and academic tourism [10].

Outbound tourism is the most developed type of tourism in Kazakhstan: the country's residents travel to Europe, America, Middle East, and South-Eastern Asia. In 2017, there were 23,524.9 thousand of tourists, out of whom $10,260.8$ were outbound tourists; 7,701.2, inbound tourists; and 5,562.9, domestic tourists ${ }^{5}$. In this paper, we are going to focus on inbound and domestic tourism in Kazakhstan.

According to the Statistics Committee of the Ministry of National Economy, the structure of inbound tourism by trip purpose looks the following way (Table 1).

Out of 12,117 visitors arrived in Kazakhstan in June 2017, 46\% came to see friends and family (which does not exclude other purposes); 20.6\%, for recreation; and $24.6 \%$, were business travellers. The remaining $8.8 \%$ had other purposes.

${ }^{2}$ Decree of the Government of the Republic of Kazakhstan of 30 June 2017 No 406 Roadmap for Tourism Development in Kazakhstan until 2023. Retrieved from https://online.zakon. kz/Document/?doc id $=39370590$

3 International Tourism, Number of Arrivals. Kazakhstan. Workbank. World Development Indicators. Retrieved from http://mecometer.com/topic/international-tourism-number-of-arrivals

${ }^{4}$ Summer Holiday in Kazakhstan? Astana Eases Visa Restrictions to Attract Tourists. Retrieved from https://www. theguardian.com/world/2014/jul/17/kazakhstan-eases-visa-restrictions-attract-tourists

${ }^{5}$ Statistics Committee, Ministry of National Economy, Kazakhstan (2018) Key Indicators of Tourism. In: Statistical Bulletin. Astana. 
Table 1

Distribution of inbound travellers by the purpose of visit in June 2017

\begin{tabular}{|l|r|}
\hline \multicolumn{1}{|c|}{ Purpose } & Number of visitors \\
\hline Leisure, recreation and holiday & 2,498 \\
\hline Visiting friends and family & 5,573 \\
\hline Education and professional training & 336 \\
\hline Health and medical treatment & 408 \\
\hline Religion and pilgrimage & 110 \\
\hline Shopping & 163 \\
\hline Transit & 37 \\
\hline Business & 2,992 \\
\hline Total & 12,117 \\
\hline
\end{tabular}

Source: Statistics Committee, Ministry of National Economy, Kazakhstan (2018) Distribution of Inbound Travellers by the Purpose of Visit. In: Statistical Bulletin. Astana.

It should be noted that diversification of tourist packages is insufficient, which makes the country unattractive for foreign tourists and is detrimental to the revenues of tourist companies. In 2017, the total volume of hospitality services in Kazakhstan was 108,359,760.4 thousand tenge, which accounted for $2.1 \%$ of the country's GDP. Art, entertainment and leisure accounted for $1.8 \%$. Out of 7.7 million of inbound tourists, 1.3 million or $16.4 \%$ used the services of resort facilities, hotels, and facilities located in protected natural areas ${ }^{6}$.

\section{Tourism diversification and economic development in Kazakhstan}

To analyze the connection between tourism diversification and characteristics of Kazakhstan's economic development we need to look at the key indicators (Table 2).

Table 2

Key indicators of macro-economic development in Kazakhstan in 2013-2017

\begin{tabular}{|r|r|r|r|r|r|}
\hline \multirow{2}{*}{ Year } & \multicolumn{5}{|c|}{ Indicator } \\
\cline { 2 - 6 } & $\begin{array}{c}\text { GDP (mil- } \\
\text { lion tenge) }\end{array}$ & $\begin{array}{c}\text { Tenge ex- } \\
\text { change rate } \\
\text { (USD/KZT) }\end{array}$ & $\begin{array}{c}\text { Unem- } \\
\text { ploy- } \\
\text { ment (\%) }\end{array}$ & $\begin{array}{c}\text { Infla- } \\
\text { tion } \\
\text { (\%) }\end{array}$ & $\begin{array}{c}\text { The } \\
\text { number } \\
\text { of SMEs }\end{array}$ \\
\hline 2013 & $35,999,025.1$ & 152.3 & 5.2 & 4.8 & 888,233 \\
\hline 2014 & $39,675,832.9$ & 179.19 & 5.0 & 7.4 & 926,844 \\
\hline 2015 & $40,884,133.6$ & 221.73 & 5.1 & 10.4 & $1,242,579$ \\
\hline 2016 & $46,971,150.0$ & 342.16 & 5.0 & 8.5 & $1,106,353$ \\
\hline 2017 & $53,101,281.8$ & 326 & 4.9 & 7.1 & $1,145,994$ \\
\hline
\end{tabular}

Source: Statistics Committee, Ministry of National Economy, Kazakhstan (2018) Key Indicators of Socio-Economic Development of the Republic of Kazakhstan. In: Statistical Bulletin. Astana; $\left(^{*}\right)$ Average Official Foreign Currency Rates in the Period 2013-2017. National Bank of the Republic of Kazakhstan. Retrieved from http://nationalbank.kz/?docid=763\&switch=russian

${ }^{6}$ Statistics Committee, Ministry of National Economy, Kazakhstan (2018). Key Indicators of Tourism. In: Statistical Bulletin. Astana.
As Table 2 illustrates, there is a stable growth in the GDP in each period; the national currency is unstable (since 2013, the dollar-tenge exchange rate has changed by 138\%); the level of unemployment is relatively stable; inflation is volatile, although it does not reach the critical values; the number of small- and medium-sized businesses (SMEs) is growing.

If we compare these indicators with the volume of services (Table 3), we will see the correlation between the development of tourism industry and the key economic indicators.

Table 3

Volume of services provided by accommodation facilities in different years (ths. tenge)

\begin{tabular}{|r|r|}
\hline Year & \multicolumn{1}{|c|}{ Volume of services } \\
\hline 2013 & $59,714,164.2$ \\
\hline 2014 & $72,401,941.1$ \\
\hline 2015 & $72,597,228.3$ \\
\hline 2016 & $82,853,434.6$ \\
\hline 2017 & $108,359,760.4$ \\
\hline
\end{tabular}

Source: Statistics Committee, Ministry of National Economy, Kazakhstan (2018). Volume of Services Provided by Accommodation Facilities. In: Statistical Bulletin. Astana.

The results of our calculations are shown in Table 4.

Coefficients of correlation between macro-economic indicators and the volume of services provided by accommodation facilities

\begin{tabular}{|l|r|}
\hline \multicolumn{1}{|c|}{ Pairs of indicators } & $\begin{array}{c}\text { Correlation } \\
\text { coefficient }\end{array}$ \\
\hline GDP - Volume of services & 0.98 \\
\hline Tenge exchange rate & 0.82 \\
\hline Unemployment - Volume of services & -0.90 \\
\hline Inflation - Volume of services & 0.17 \\
\hline The number of SMEs - Volume of services & 0.52 \\
\hline
\end{tabular}

Note: based on the data from Table 2 and 3.

Thus, there is virtually no correlation between inflation and the volume of services provided by accommodation facilities. There is, however, a very strong inverse correlation between unemployment and the volume of services since the development of tourism means more jobs and is associated with the decreasing rate of unemployment. There is also a strong correlation between the GDP and the volume of services as both of these indicators have been growing steadily. We cannot be absolutely sure about the impact of the GDP on the growth of tourism or vice versa. The correlation between the volume of services and the two remaining indicators is more evident, though. 
For instance, the drop in tenge value caused an increase in the demand for services because foreign tourists were attracted by lower prices. Thus, the falling exchange rate of the national currency had a positive impact on inbound tourism. There is a weak correlation between the number of SMEs and the volume of services. Therefore, we can conclude that tourism accounts for an insignificant share in the overall increase in the number of SMEs in the country and that the influx of new companies in the tourism industry in Kazakhstan is comparatively small.

This fact is supported by the data of the Statistics Committee, which recorded a 9\% decline in the sphere of inbound tourism. In the fourth quarter of 2017, Kazakh tourists preferred to travel abroad (63\% of respondents against $49 \%$ in 2016). They were attracted by the better developed tourist infrastructure, better cost-quality balance, and the wider choice of accommodation facilities. At the same time, in Kazakhstan, there was a rise in demand for overseas tours and a decrease in the employment rate in the tourism sector in comparison with 2016. Business owners themselves pointed out that the decline in demand for tourist services had the biggest influence on the economic performance of their companies.

To gain a better understanding of the problem, let us look at the reports published by international organizations. The World Bank pointed out the three major risks faced by the country's economy: the weaker external demand, escalation of problems in the banking sector, and weak implementation of the structural reforms. Therefore, it is recommended that the government should make progress in deepening structural reforms aimed at diversification of economy and to enhance the country's economic potential in non-oil sectors. According to the report, the oil sector was the main driver of economic growth, as oil output increased by $12.5 \%$ in the first nine months of 2017 due to the launch of production at the off-shore oil field Kashagan ${ }^{7}$. Another factor contributing to this trend was the increase in oil prices by $24 \%$. Additionally, the construction sector rebounded due to new large capacity expansion projects in the oil sector.

In other sectors, there is a growth in the production sphere, agriculture, transport and trade.

World Bank Kazakhstan's Economy is Rising - It is Still All About Oil. Country Economic Update. Retrieved from http://www.worldbank.org/en/country/kazakhstan/publica$\underline{\text { tion/economic-update-fall-2017 }}$
Despite the rise of foreign trade, the volume of direct foreign investment has shrunk.

According to the World Bank's forecast, if Kazakhstan manages to implement its structural reforms successfully, it will help increase diversification and the potential of the country's economy. The 100 Concrete Steps program and privatization are expected to reduce the role of the state in economy and enhance trade in sectors other than oil and gas. A robust fiscal and monetary policy can maintain the economic and price stability, which help attract more investment to the nonoil sectors. The government still needs to address such problems as the prevalence of state-owned companies in economy, the lack of qualified workforce, the macro-economic vulnerabilities, and the lack of interregional cooperation ${ }^{8}$.

The decline in the real income of the population and the falling national currency, which make exchange transactions unprofitable, hamper the development of outbound tourism. At the same time the development of inbound and domestic tourism is difficult due to the underperforming national tourist companies, which fail to devise and promote tourist routes to destinations in Kazakhstan. Theoretically, it would be possible to stimulate companies through affordable business loans. This, however, seems problematic taking into consideration the unstable banking sector and the comparatively high refinancing rate in Kazakhstan.

Thus, Kazakhstan has potential for tourism development but finds it hard to realize it, both in terms of domestic and international tourism. As of 2016, there are 2,031 tourist companies operating in the country. There are 2,754 accommodation facilities with 128,062 beds, which is $16.6 \%$ more than in 2015. The occupancy rate in 2016 was $23.8 \%$, that is, over $75 \%$ of beds were vacant at the same time ${ }^{9}$.

According to the Roadmap for Tourism Development in Kazakhstan Until 2023, "accommodation prices in places with a high level of hospitality services are much higher than in their counterparts in other tourist destinations of the world. The average price for a standard room in a $5^{*}$ hotel

World Bank Kazakhstan's Economy is Rising - It is Still All About Oil. Country Economic Update. Retrieved from http://www.worldbank.org/en/country/kazakhstan/publication/economic-update-fall-2017

${ }^{9}$ Decree of the Government of the Republic of Kazakhstan of 30 June 2017 No 406 Roadmap for Tourism Development in Kazakhstan until 2023. Retrieved from https://online.zakon. $\mathrm{kz} /$ Document/?doc id $=39370590$ 
in Astana or Almaty is about 20\% higher than the average price for a similar room in top European cities and tourist destinations" ${ }^{\prime 1}$. Exorbitant prices make tours to Kazakhstan even more expensive and are detrimental to the country's competitiveness on the global market.

Figure illustrates the demand for Kazakhstan as a tourist destination ${ }^{11}$.

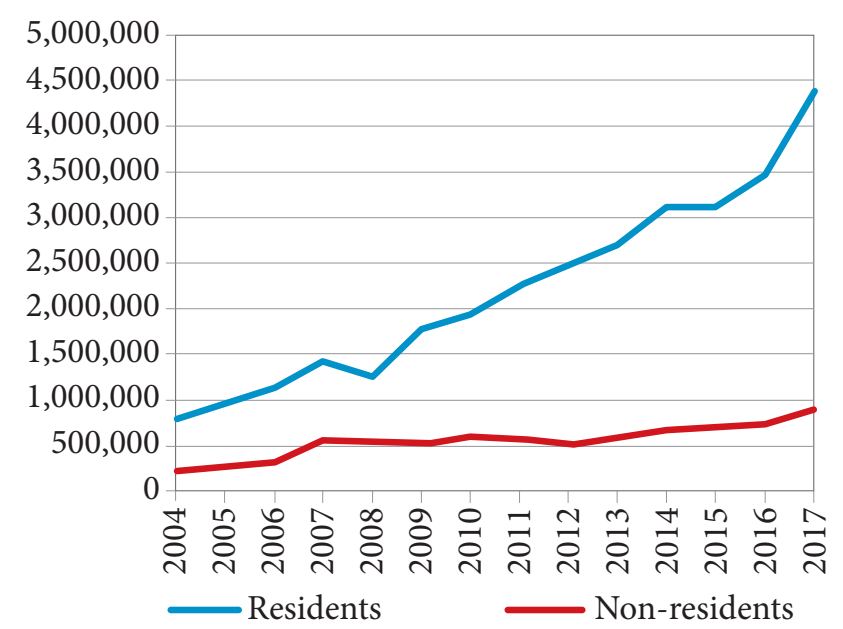

The number of tourists in Kazakhstan

This graph shows that the growth rates of domestic tourism exceed those of inbound tourism; the volume of domestic tourism is higher than that of inbound tourism; in general, there has been a growing demand for tourism, although 2007-2008 and 2014-2015 were the periods of recession. In 2014 and 2015, for instance, domestic tourism was in decline while inbound tourism failed to show any signs of growth. This slowdown was likely to be caused by the falling tenge, which mostly affected the country's residents.

The majority of tourists $(82.8 \%)$ come from Kazakhstan; as for tourists from other countries, Russia accounts for the largest share of non-resident tourists (31.4\%); China, 7.4\%; the USA, 5.9\%; Turkey, 5.9\%; Germany, 4.5\%; $2.9 \%$, Italy; and $42 \%$ come from other countries ${ }^{12}$.

${ }^{10}$ Decree of the Government of the Republic of Kazakhstan of 30 June 2017 No 406 Roadmap for Tourism Development in Kazakhstan until 2023. Retrieved from https://online.zakon.kz/ Document/?doc id=39370590

${ }^{11}$ Statistics Committee, Ministry of National Economy, Kazakhstan (2018). Economic Activity of Enterprises in Kazakhstan. In: Statistical Bulletin. Astana; Statistics Committee, Ministry of National Economy, Kazakhstan (2018). The Number of Domestic Tourists using Tourist Accommodation Facilities (Residents). In: Statistical Bulletin. Astana.

${ }_{12}$ Decree of the Government of the Republic of Kazakhstan of 30 June 2017 No 406 Roadmap for Tourism Development in Kazakhstan until 2023. Retrieved from https://online.zakon.kz/ Document $/$ ?doc id=39370590
As for the purpose of trips, business travellers prevailed (54.1\%). 45.6\% were holiday-makers. The majority were private tourists $(75.4 \%)$ while business travellers accounted for $16.2 \%{ }^{13}$.

Therefore, we can conclude that tourism in Kazakhstan mostly relies on the country's residents and on business trips of non-residents, that is, the potential of recreational, sport, cultural, ecological and religious tourism is not fully realized.

International experience shows that in order to increase the share of tourism in the country's GDP, it is essential to attract more foreign holiday-makers ${ }^{14}$. For instance, Europe is overpopulated, which means that European tourists would welcome the opportunity to escape crowds of tourists and enjoy being along with nature ${ }^{15}$.

Even though the tourism infrastructure has been improving in the recent years, high prices still discourage foreign tourists from choosing Kazakhstan as a place of destination. In this respect, Kazakhstan cannot cope with the competition from its neighbours - Uzbekistan and Kyrgyzstan ${ }^{16}$. It is possible to lower the prices and improve the quality of services only if there is healthy competition on the market. Therefore, a set of measures should be developed to attract more foreign investment, create a favourable investment climate and address other problems that impede the development of tourism in Kazakhstan.

As the country is now going through major structural changes, the following types of diversification in tourism seem to be the most promising: business, transit, ethnic, educational, event, and academic tourism. The rising share of SMEs in tourism (hostels and private tourist agencies) will make it possible to increase the price and product range.

The most significant problems that need to be dealt with are the poorly developed transport and information infrastructure, the unstable banking sector and unaffordable business loans, hamper-

${ }^{13}$ Decree of the Government of the Republic of Kazakhstan of 30 June 2017 No 406 Roadmap for Tourism Development in Kazakhstan until 2023. Retrieved from https://online.zakon. kz/Document/?doc id $=39370590$

${ }^{14}$ Web-Site of Business Portal Kapital.kz. Retrieved from https://kapital.kz/economic/71242/kakie-nishi-privlekatelny-dlya-investicij-v-turizm.html

${ }^{15}$ Web-Site of Business Portal Kapital.kz. Retrieved from https://www.zakon.kz/4450912-turizm-v-kazakhstane-glaza$\underline{\text { mi.html }}$

${ }^{16}$ Web-Site of Business Portal Kapital.kz. Retrieved from https://kursiv.kz/opinions/2018-07/turizm-kazakhstana-itogi-2016-perspektivy-2017-goda 
ing the development of private entrepreneurship, the lack of qualified personnel in the sphere of hospitality, marketing and catering. With its current level of prices and services, Kazakhstan as a tourist destination is unable to compete with its international counterparts. Taking into account all these considerations, the main form of diversification in Kazakhstan should be horizontal, that is, the search for new markets.

\section{Conclusion}

Our analysis leads us to the following conclusions:

1. Diversification of tourism, that is, enhancement of the diversity of markets, products and services within the industry, is an important process influenced by different external factors. Tourist companies are heavily dependent on the available infrastructure, on natural, cultural and political conditions.
2. Only a very small share of inbound and outbound travellers in Kazakhstan are tourists; the majority are business travellers. The fact that Kazakhstan attracts few tourists can be explained by the poor quality of the existing transport infrastructure, the poor quality of services and high prices, which means that the country's tourism market is unstable and undeveloped and that its potential is largely underrealized.

3. Diversification may spur the development of recreational, sport, cultural, ecological and religious tourism.

4. To ensure sustainable economic development, Kazakhstan needs to reduce its dependence on the oil and gas sector, provide sufficient support for its banking sector and conduct effective structural reforms. Kazakhstan should also attract more foreign investment (for example, the case of the Chinese infrastructure project Western Europe - Western China).

\section{References}

1. Vasilieva, A. V. (2013). Tourism as an Area of Diversification of Regional Economy. Ekonomika i upravlenie, 7, 89-93. (In Russ.)

2. Babenko, O. (2014). Diversification Strategy of the Tourist Enterprises. Ekonomichnyj chasopys-XXI, 11-12, 128-130. (In Ukr.)

3. Kolosova, E. V. (2011). Personnel Diversification in Tourist Enterprises in the Period of Economic Recession. Sovremennaya nauka: aktualnye problemy teorii i praktiki, 2, 27-29. (In Russ.)

4. Domnyach, S. S. (2017). Lateral Diversification of Tourism Agencies In: Science Today: Problems and Future Development. Conference Proceedings, March 29, 2017. Vologda, Marker, 55-56. (In Russ.)

5. Kurchenkov, V. V., Fetisova, O. V., Tyutyusheva, A. G., \& Matina, E. S. (2016). Priorities of Diversification of the Structure of Regional Tourist Complex. Regionalnaya ekonomika. Yug Rossii, 2, 57-64.

6. Makhlyuf A., \& Karpunina, E. K. (2017). Role of Travel and Hotel Business in Ensuring Social and Economic Development of National Economy. Socio-Economic Phenomena and Processes, 12(2), 64-67. (In Russ.) doi: 10.20310/1819-8813-2017-12-2-64-67

7. Kirillina, V. M., Kolesnikova, N. V., Kolesnikov, N. G., Plotnikova, V. S., Zakharchenko, S. O., Isakova, N. A., et al. (2016). Types of Tourism and their Development in the Republic of Karelia. Penza, Nauka i prosveschenie. (In Russ.)

8. Ashugatoyan, S. G. (2017). Diversification Strategy as a Way of Solving Problems of Turkish Tourist Industry. Vestnik of National Tourism Academy, 4, 44-45. (In Russ.)

9. Ovcharov, A. O. (2012). Tourism in Russia: Trends, Risks, and Potential. Moscow: INFRA-M. (In Russ.)

10. Nazarkina, V. A., Vladykina, Y. O., Vorotnikova, E. Y., Komarova, O. S., Maletin, S. S., Strebkova, L. N., et al. (2014). Type and Trends of Tourism Development. Novosibirsk: Ministry of Education and Science of the Russian Federation, Novosibirsk State Technical University. (In Russ.)

\section{Information about the author}

Aksanat Zh. Panzabekova - PhD in Economic Sciences, Associate Professor, Deputy Director for Science of the Institute of Economics of the Committee of Science of the Ministry of Education and Science of the Republic of Kazakhstan (Almaty, Kazakhstan); e-mail: aksanat@mail.ru. 